Russians under the decisive influence of social and political discourse. At the same time, the influence of long-term sociocultural and generational factors on the system of ideas about foreign countries is less noticeable.

Keywords: Russian national-state identity, image of the USA, images of us and them, political perception, political communication, socio-political discourse

КРУТАКОВ Леонид Викторович - доцент департамента политологии Финансового университета при Правительстве РФ (119146, Россия, г. Москва, Фрунзенская наб., 14; krutakov@таil.ru)

\title{
КОНТУРЫ НОВОГО МИРОПОРЯДКА: ИЗМЕНЕНИЕ ПРИНЦИПОВ И ПРАВИЛ КОНУРЕНЦИИ ЗА ЭНЕРГЕТИЧЕСКИЕ РЕСУРСЫ
}

\begin{abstract}
Аннотация. В статье предпринята попытка проанализировать финансовый кризис 2008 г., последующую стагнацию мировой экономики с развитием глобального политического кризиса. Автор приходит к выводу, что кризис носит не циклический, а системный характер, изменению подлежат не отдельные механизмы и институты, а вся модель мировой экономики. Ее акторами и субъектами являются не транснациональные корпорации, а национальные государства. «Плоский мир" Томаса Фридмана оказался иллюзией, Вестфальский формат возвращается. Глобальная конкуренция вновь вышла на уровень межгосударственных отношений. Конкурентная борьба идет за природную ренту, прежде всего за энергетические ресурсы, которые являются мотором роста мировой экономики.
\end{abstract}

Ключевые слова: кризис, рента, мировая экономика, финансовая глобализация, эффекты роста, ОПЕК, энергетика, углеводороды, инфраструктура, «вертолетные деньги», количественное смягчение

$\mathrm{K}^{\mathrm{s}}$ ризис 2008 г. и последующая рецессия поставили на повестку дня вопрос об исчерпанности существующей модели мирового развития. Количественное смягчение ФРС США и эмиссионные программы Центробанков Англии, Японии и ЕС симулируют рост экономики. Эмиссия замаскировала, но не решила проблему. Из каждых 100 долларов глобальных финансовых проводок только 2 доллара обслуживают товарные сделки и услуги, остальное - спекуляции [Ulrich, Wijkman 2018]. Дисбаланс в мировой экономике нарастает. Инвестиции заперты в ценных бумагах на фондовой бирже, доступ к реальному сектору мировой экономики заблокирован санкциями, торговыми и реальными войнами. Оффшорная (скрытая) система межстранового перетока капитала дезавуирована. Рыночный механизм регулирования мировых товарных потоков поставлен на «стоп-кран», а новый механизм не предложен. Точнее, находится в стадии обсуждения. Мир вынужденно возвращается к «старому» формату (Вестфальская система) межгосударственных отношений. Зоной конфликта является правовой контекст мировой экономики. Связи за пределами национальных юрисдикций делегитимированы, идет поиск новых принципов и правил межнациональных отношений. Главный вопрос - кому должен принадлежать мандат на принуждение к порядку: ООН или «всему цивилизованному миру» во главе с США и НАТО. Субъекты глобального рынка конкурируют за первоисточник экономического роста, за энергетические ресурсы, которые были и остаются топливом мировой экономики. Суть конфликта не в абстрактных темпах экономического роста, а в «субъективном праве» - праве на присвоение эффектов роста (принципы и способы раздела совокупной мировой прибыли). 


\section{Концепция «полного мира»: новый передел или новая модель развития?}

Сегодня, спустя 10 лет после финансового кризиса, можно утверждать, что мировая экономика была целенаправленно погружена в состояние искусственной комы. Количественное смягчение оказалось не чем иным, как покупкой времени (отсрочки) для поисков политического решения проблемы. Вопрос заключается в фатальности происшедшего: экономическая модель, реализуемая вот уже более 300 лет, окончательно исчерпала себя, или проблема носит тактический характер? Неолиберализм сводит кризис исключительно к темпам и условиям экономического роста, определяет его как результат иррациональных («политическое безумие») действий Ирана, России, Турции, Китая. Чтобы выйти из кризиса, надо лишь наказать виновных и вернуть в лоно заблудших. Неотрадиционализм в оценке проблематики отдает предпочтение политэкономии. В центр анализа ситуации ставится динамика национального богатства и социальное неравенство; не затраты общества (ВВП), а его благосостояние. Речь идет не об иной методике оценок, а о смене модели взаимодействия национальных экономик, шире - культур, образов жизни. Тектонический сдвиг в подходах произвел «Капитал в двадцать первом веке» Томаса Пикетти. Автор доказал, что в условиях свободного рынка доход на капитал (процент) всегда выше роста экономики. Иными словами, рента как способ перераспределения экономических эффектов была и остается основой организации общества, а рост благосостояния стран Запада в середине XX в. был вызван политическими решениями [Piketty 2014]. Еще одной реперной точкой стал доклад Секретариата конференции ООН по торговле и развитию (UNCTAD) «O торговле и развитии, 2014». Главный тезис доклада: благосостояние стран Запада создавалось не внутренней игрой рынка, а целенаправленным перераспределением мировых ресурсов в свою пользу. Запад выстроил дискриминационную модель глобального рынка. Развивающимся странам предложили отказаться от протекционизма (национального приоритета), объявив его причиной их отсталости. В обмен на отказ был обещан рост за счет притока прямых иностранных инвестиций (ПИИ), но распоряжаться эффектами роста в свою пользу им запретили [Global governance... 2014]. Стержнем модели стал обмен финансовых методик сопровождения роста (кредит) на источники роста (трудовые и природные ресурсы). В цене $i P a d$ оплата труда китайских рабочих занимает $2 \%$, сырье - 31\%, прибыль - 30\%, а затраты на рекламу - $15 \%$ [Kramer, Linden, Dedrick 2011]. Более наглядно модель мирового рынка демонстрирует соотношение прибыли и издержек в энергетике. В 2000 г. Европу захлестнули «бензиновые бунты»; вину попытались возложить на ОПЕК. Тогда глава ОПЕК Рилвану Лукман заявил, что в конечной стоимости барреля очищенной нефти только $16 \%$ принадлежит экспортерам, остальные $84 \%$ - это налоги странпотребителей. Модель глобального рынка подрывала государственные стратегии роста развивающихся стран (риски национальных элит). Использование ПИИ в базовых отраслях экономики, связанных с извлечением природной ренты, неизбежно ставит вопрос о собственности на ключевые источники роста национальных экономик (конкурентные преимущества). Россия вопрос о национализации стратегии развития решила в 2003 г., предотвратив продажу ЮКОСа американскому гиганту ExxonMobil. Возрождение Роснефти, знаменитая «мюнхенская речь», Украина и санкции - всего лишь следствия этого события. Доклад $U N C T A D$ рекомендует отказаться от международных инвестиционных договоров в пользу национального законодательства (внутренний кредит). Фактически свобода движения капитала (базовый постулат неолиберализма) названа причиной дисбаланса мировой экономики и причиной глобального кризиса. Попытка стимулировать экономику эмиссионно увеличила дисбаланс 
и глубину потенциального (скрытого) кризиса. Существующая модель развития (рыночная экспансия) уперлась в географический и временной предел. Рост стал нерентабелен (отрицательные ставки по депозитам и ОФЗ), общество деградирует, и, если модель не сменить, нас ждет цивилизационный коллапс [Daly 2005]. Концепция «полного мира» Г. Дейли, который также отказался от технократической трактовки кризиса, легла в основу юбилейного доклада Римского клуба «Cоте On! Капитализм, близорукость, население и разрушение планеты». Испытанию подвергаются основы социально-политического уклада общества, его культурный и моральный облик. Члены Римского клуба вслед за Карлом Поланьи утверждают необходимость построения согласованного или инклюзивного мира (мира миров). «Полный мир» меняет объект глобальной конкуренции. Возобновляемые ресурсы (капитал, труд) отходят на второй план. На первое место встают ограниченные (конечные) ресурсы. Способ распределения эффектов роста (денежная рента) не имеет смысла при утере контроля над первоисточником роста - природной рентой. Меняются не только объект конкуренции, но и ее субъектность. Собственность (источник ренты) на национальном уровне легитимирует консенсус общества, а на международном паритет сил. Соответственно, «полный мир» ведет к консолидации национального контура и обострению международных противоречий. На смену борьбе корпораций по правилам приходит борьба государств без правил (за изменение правил). Конструкт сетевого общества уступает место новой «иерархии иерархий». Разрушение глобального проекта идет в виде роста национализма (реанимация культурных кодов), регионализма (формирование новых зон доверия) и протекционизма (приоритет национальных целей).

\section{Поле битвы - мировая энергетика}

Системную проблему финансовой глобализации диагностировал глава ФРС США Алан Гринспен. Еще в начале нулевых он заявил, что избежать взрыва фондового пузыря долларовой массы можно единственным способом - открыть ему доступ к внешним активам. Базовым риском модели является принципиально «чужой» источник мировых денег. Сбережения генерируют производящий и ресурсный сектор мировой экономики, а объем и условия выделения инвестиций определяет финансовый центр. Модель требует ликвидации политической субъектности ресурсных и производящих стран. Запустив в 2008 г. количественное смягчение (замена сбережений долгами будущего), ФРС США доказала, что в общей финансовой системе национальные режимы не могут обеспечить сохранность своих денег. Изъятие средств из ресурсного и производящего сектора обострило политические разногласия, но проблему «чужих» денег не решило. Актуальность требований Гринспена только возросла. За первые 2,5 года реализации программы количественного смягчения денежная масса США увеличилась почти в 3 раза, а общемировая за 10 послекризисных лет - почти на 40\%. При этом общая капитализация ресурсных и производящих экономик из-за войн и санкций упала. «Финансовый пузырь» достиг невероятных размеров. Если деньги не найдут путь к активам, взрыв неизбежен. Преимущество принадлежит энергетическим активам, и не только в силу колоссальной маржинальности (финансовая емкость): в отличие от трудовых ресурсов и технологий, углеводороды ценны сами по себе, без учета местного населения. Сегодня можно с известной долей уверенности говорить, что подрыв единого механизма управления мировой экономикой был спровоцирован попыткой производящего и ресурсного сектора выработать новые принципы хозяйственной кооперации в обход интересов финансового центра. Экспансия Китая в энергетический сектор началась в конце 1990-х. Пекин, 
в отличие от западных правительств, не выдвигал требований о правах человека по отношению к партнерам. Три китайские нефтяные компании $(C N P C$, Sinopec, $C N O O C)$ при политической и инвестиционной поддержке государства ринулись завоевывать мир, ломая сложившиеся на рынке нормы и правила. С 2005 по 2013 г. общий объем сделок CNPC, Sinopec, CNOOC по приобретению зарубежных активов составил 123,5 млрд долл. [Jiang, Ding 2011; 2014]. K 2014 г. зарубежная добыча китайских компаний выросла в 4 раза (126 млн т н.э. в год). Экспансия Китая в энергетику шла на фоне падения эффективности мировых лидеров рынка. С 2000 по 2015 г. ExxonMobil, Shell, BP, Chevron, Total в 4 раза увеличили инвестиции в разведку и добычу (с 29 до 121 млрд долл.). При этом объем добычи нефти упал с 507 до 443 млн т., а их доля в мировых запасах нефти снизилась с 3,5\% до 2,2\%. Совокупный задействованный капитал вырос с 310 до 902 млрд долл., а его рентабельность рухнула с 18,4\% до 4,6\% [Силкин 2017]. Последняя цифра особенно показательна. Она показывает, как «вертолетные деньги» ${ }^{1}$ поднимали стоимость западных компаний (рост экономики) вопреки падению уровня добычи, запасов и доходности. Параллельно рос объем добычи нефтяных компаний Ближнего Востока и России, а их капитализация падала (политические риски). Высокие темпы роста и низкая стоимость труда позволяли Пекину действовать стратегически, вопреки конъюнктуре рынка. Пока США и Россия вели политическую борьбу за контроль над поставками нефти и газа из Средней Азии в Европу, Китай развернул инфраструктуру региона в свою сторону, используя торгово-инвестиционное партнерство. Схожими методами Китай действовал на Ближнем Востоке, в Африке и Латинской Америке. Решающий прорыв произошел в сторону России. Нефтепровод «Восточная Сибирь - Тихий океан» с ответвлением в Китай, проект газопроводов «Алтай», «Сила Сибири» и 30-летний контракт на поставки газа запустили инфраструктурное переформатирование Евразии. Союз России (ресурсы) и Китая (производство) установил военно-политический паритет с транзакционным сектором (НАТО). Конфликт «хозяйствующих субъектов» вышел в публичное пространство. Заключение Москвой и Пекином газового «контракта века» по времени совпало с украинским Майданом и антироссийскими санкциями. С 2004 г. произошла фактическая смена внешнеполитической доктрины США. В октябре 2004 г. на саммите $G-8$ в Си-Айленде Джордж Буш-младший ее озвучил под названием «Большой Ближний Восток». Ее смысл заключался в отказе от стабильности в пользу демократизации, а ее сутью стала дезинтеграция ресурсного и производственного сектора мировой экономики. По СНГ покатится волна «цветных революций» (включая неудавшиеся в Казахстане, Азербайджане и Белоруссии), на Ближнем Востоке расцветет Арабская весна. Россия и Ближний Восток как были источниками топлива для мировой экономики, так ими и остаются. Географию не изменишь, изменить можно политическую географию. «Демократизация» Ближнего Востока, рост сланцевой добычи в США, блокировка Эр-Риядом квот ОПЕК на добычу, биржевая игра и «нелегальные» поставки Исламским государством ${ }^{2}$ иракской нефти на мировой рынок заблокировали ресурсный фактор. Курс на сближение Китая и России заставил США подорвать единство финансового рынка. Трехсторонний (финансы-производство-ресурсы) глобальный конфликт экономических секторов общей производственной цепочки трансформировался в двухсторонний

1 «Вертолетные деньги» - термин, придуманный американским экономистом, лауреатом Нобелевской премии Милтоном Фридманом. Концепция заключается в том, чтобы передать деньги напрямую к домохозяйствам, что, в свою очередь, приведет к инфляции и будет стимулом для роста экономики.

2 Его деятельность запрещена в России. 
политический конфликт развивающихся (недоинвестированных) и развитых (переоцененных) стран. Напряжение растет, каждая из сторон конфликта блефует и экстренным порядком (где «томагавками», где «калибрами», где денонсацией договора по РСМД) расширяет «зоны доверия» и «зоны контроля» (они не всегда совпадают). Определить временной горизонт этого противостояния сложно, но победителем из него выйдет сторона, под контролем которой окажется больше первичных ресурсов роста, прежде всего энергетических.

\section{Заключение}

Рост значимости первичных ресурсов и превосходство распределительных схем над рыночными механизмами (влияние государства в жизни общества) необходимо расценивать как объективную (естественную) реакцию больших социальных систем на удлинившееся плечо финансового инжиниринга (рост рисков). Подобная реакция вызвана вопросами не раздела прибыли, а долговременной устойчивости (выживание). Мир втягивается в новое двустороннее противостояние (биполярье). Его исход будет зависеть от того, на чьей стороне (финансового сектора или производственного) окажутся мировые ресурсы. Определяющим фактором станет способность обеспечивать эффективный суверенитет. Страны, не способные установить жесткий контроль над национальным контуром экономики (слабопроектные территории), будут подвергнуты новому переделу. Страны, готовые и способные отстаивать свое конкурентное преимущество на глобальном рынке, примут участие в выработке новой формулы безопасности, новых правил функционирования мировой экономики и новых принципов раздела совокупной прибыли. Глобальный проект управления мировой экономикой из единого центра на базе долговой модели США распадается. Происходящее видится нам не как исторический процесс, а как девиация - регресс и отклонение. На самом деле, кризис обнажил каркас конструкции общества, снял с рыночной модели тюнинговый обвес. Обострение борьбы за контроль над энергетическими ресурсами планеты свидетельствует, что мир вступил в очередной период глобальной волатильности. Все предыдущие периоды заканчивались изнурительными войнами и заключением международного договора, фиксирующего зоны влияния центров силы, сложившихся в результате войны. Сегодня амбиции новых центров силы проявлены, процесс запущен, набрал инерционную массу, и остановить его уже невозможно. Отсидеться в стороне ни у кого не получится. Для России принципиально важно понимать, что вопрос исторической проектности решать все равно (сколько ни откладывай) придется. Страна является неотъемлемой частью глобальной цепочки производства стоимостей, изменение которой всегда сопровождается ожесточением межгосударственной конкуренции. Вопрос лишь в том, сложится новая модель мирового рынка при активном участии России, или мы примем ее как данность, спущенную нам сверху (объективный закон мироздания). Однажды - в 1991 г. - это уже произошло.

\section{Список литературы}

Силкин В. 2017. Контуры новой модели конкуренции за энергетические ресурсы. - Мировая экономика и межсдународные отношения. № 4. С. 60-70.

Daly H.E. 2005. Economics in a Full World. - Scientific American. September. Vol. 293. No. 3. P. 100-107.

Global governance and policy space for development. Trade and Development Report, 2014: Report by the Secretariat of the United Nations Conference on Trade and Development. 2014. UN. N.Y., Geneva. 212 p. 
Jiang J., Ding C. 2011. Overseas by Chinese National Oil Companies: Addressing the Drivers and Impacts. Paris: International Energy Agency. 52 p.

Jiang J., Ding C. 2014. Update on Overseas by China's National Oil Companies: Achievements and Challenges since 2011». Paris: International Energy Agency. 49 p.

Kramer K.L., Linden G., Dedrick J. 2011. Capturing Value in Global Networks: Apple's iPad and iPhone: PCIC Working Paper. URL: http://pcic.merage.uci.edu/ papers/2011/value_ipad_iphone.pdf (accessed 29.04.2019).

Piketty T. 2014. Capital in the Twenty-first Century. Cambridge; London: The Belknap Press of Harvard University Press. $685 \mathrm{c}$.

Ulrich E., Wijkman A.W. 2018. Come On! Capitalism, Short-termism, Population and the Destruction of the Planet: A Report to the Club of Rome. N.Y.: Springer Science+Business Media LLS. 220 p.

KRUTAKOV Leonid Viktorovich, Associate Professor of the Department of Political Science and Mass Communications, Financial University under the Government of the Russian Federation (49 Leningradsky Ave, Moscow, GSP-3, Russia, 125993; krutakov@mail.ru)

\section{THE CONTOURS OF A NEW WORLD ORDER: CHANGING THE PRINCIPLES AND RULES OF COMPETITION FOR ENERGY RESOURCES}

Abstract. The article attempts to analyze the financial crisis of 2008, the subsequent stagnation of the world economy with the development of the global political crisis. The author concludes that the crisis is not cyclical, but systemic one. Not individual mechanisms and institutions are subject to change, but the entire model of the world economy. Its actors are not transnational corporations, but nation states. The «flat world» of Thomas Friedman turned out to be an illusion; Westphalian format is back. Global competition has once again reached the level of interstate relations. The competition is for the natural rent, mainly for the energy resources that are the engine of global economic growth.

Keywords: crisis, rent, world economy, financial globalization, growth effects, OPEC, energy, hydrocarbons, infrastructure, helicopter money, quantitative easing 